\title{
Caralluma Acutangula Prevents Body Weight Gain in Rats Feed on Hyperlipidic Diet
}

Pare DRAMANE ${ }^{1,2}$, Hilou ADAMA ${ }^{1}$, Adrian POTÂRNICHE², Mabozou KPEMISSI ${ }^{2,3}$, Orsolya SÁRPATAKI ${ }^{2}$, Ouedraogo NOUFOU ${ }^{4}$, Alexandra I. BLIDARU ${ }^{2}$, Marian TAULESCU ${ }^{2}$, Guenne SAMSON ${ }^{1}$, Ioan MARCUS ${ }^{2}$, Sanda ANDREI ${ }^{2}$ and Bogdan SEVASTRE ${ }^{2 *}$

${ }^{1}$ Laboratory of Biochemistry and Applied Chemistry (LABIOCA), University of Ouagadougou UFR/SVT, 09 BP 848 Ouagadougou 09, Burkina Faso

${ }^{2}$ Faculty of Veterinary Medicine, University of Agricultural Science and Veterinary Medicine, Manastur Street. 3-5, 400372, Cluj-Napoca, Romania.

${ }^{3}$ Faculty of Sciences, University of Lome, Togo

${ }^{4}$ Research Institute for Health Sciences (IRSS) 03 BP 7192 Ouagadougou 03, Ouagadougou, Burkina Faso.

*corresponding author: bogdan.sevastre@usamvcluj.ro

Bulletin UASVM Veterinary Medicine 75(2)/2018

Print ISSN 1843-5270; Electronic ISSN 1843-5378

doi:10.15835/buasvmcn-vm:006617

\begin{abstract}
Caralluma acutangula (Decne.) (CA) (Asclepiadaceae) is a medicinal plant traditionally used in Burkina Faso for the management of weight. The aim of this study was to evaluate the effect of extract of CA on body weight, food intake, blood biochemistry parameters on experimental obesity rat model. One group received CA $400 \mathrm{mg} / \mathrm{kg}$ b.w. per day and was fed on hyperlipidic diet (HD), while the control group received HD only for three weeks long. The phytochemical investigation of extract showed a high total phenolic content (36.21 $1.36 \mathrm{mg}$ GAE $/ 100 \mathrm{mg}$ of extract) and total flavonoids ( $4.98 \pm 0.31 \mathrm{QE} / 100 \mathrm{mg}$ of extract). In the end, CA-HD treated group had a body weight loss of $2 \%$, compared to HD group who presented a body weight gain of $15 \%$. The CA-HD treated group showed also a lower levels of plasma triglyceride $(136.57 \pm 13.82 \mathrm{mg} / \mathrm{dL})$ and glycemia $(187.74 \pm 31.16 \mathrm{mg} / \mathrm{dL})$ compared to HD $(206.02 \pm 23.82$ and respectively $230.96 \pm 79.07 \mathrm{mg} / \mathrm{dL})(\mathrm{p}<0.05)$. CA extract also showed a good anti-oxidant activity in vivo (effect on antioxydant enzyme (MDA, GPX, SOD) and in vitro (inhibition of DPPH radical, ferric ion reduction). This study showed that CA is a potential natural remedy for the control of body weight and alleviation of obesity related disease.
\end{abstract}

Key words: phytotherapy, obesity, antioxidant activity

\section{Introduction}

Obesity is a chronic condition characterized by an excess of body fat that cause body weight gain (Seidell and Flegal, 1997). In general, this metabolic disorder results from an imbalance between energy intake and that spent (Woods et al., 1998). Obesity is a major concern for public health, it represents the fifth-largest mortality risk factor worldwide, and nearly three million people die each year because obesity associated disorders. Obesity is mostly associated with diseases such as hypertension, heart failure, stroke, type II diabetes, insulin resistance, dyslipidemia, and certain type of cancers. Long regarded as a problem of "rich" countries, in the last years, it has been increasing dramatically in low- and middleincome countries (Seidell and Flegal, 1997). In the attempt to control body weight gain in obese patients, various pharmaceutical drugs have been produced; the most of them are of synthetic origin and present serious side effects. This is why 
finding new natural molecules effective but with no toxicity becomes an active area of research.

Carallumaacutangula (Decne.) (CA) is a species of the family Asclepiadaceae, used for century in northern Burkina Faso for the management of weight gain. It is also recommended against boils, to heal wounds as a magical plant to protect live (Schmelzer, et al., 2013). In children, it traditionally alleviates the chest pain (Wilson et al., 2014). The Caralluma sp. are known for its richness in pregnane glycosides, flavonoid glycosides, flavones, glycosides, pregnane steroids, steroidal glycosides, aromatic and nonaromatic volatile compounds, and b-sitosterol (Harish et al., 2012). Pregnane glycosides have anticancer, antiobesity, appetite suppressant, antitrypanosomal activities (Halaweish et al., 2004). Despite the fact that several pregnanes glycosides have been isolated identified in CA (Mohammed et al., 2000); there are no studies on the anti-obesity potential of CA extracts.

The aim of this study was to determine the effects of CA methanolic extracts on body weight gain, food intake, and biochemical parameters of blood in obese rats.

\section{Materials and methods}

Plant material and extraction

The whole plants of CA were harvested at Gorom-gorom (a locality located in northern Burkina Faso at $400 \mathrm{Km}$ on the road Ouagadougoukaya $\left(12^{\circ} 29^{\prime} 42.7 \mathrm{~N}, 1^{\circ} 24^{\prime} 1.2 \mathrm{~W}\right)$ during the period of March to April 2017. The species have been authenticated by Professor Millogo R. J., botanist at the UFR / SVT of the University of Ouagadougou. The samples were dried under laboratory conditions out of the sun and then pulverized and stored. $50 \mathrm{~g}$ of the vegetable powder were used for extraction by maceration in $500 \mathrm{ml}$ of methanol. The resulting mixture was stirred magnetically for 24 hours. This mixture obtained is concentrated using a rotary evaporator (Buchi 461) equipped with a vacuum pump and this concentrate was oven-dried and used for the various tests.

\section{Phytochemical investigation}

Total Phenolics Content - Total polyphenols were determined by using Folin-Ciocalteu method as described by Singleton et al. (1999). A volume of $125 \mu \mathrm{L}$ of methanol extracts $(100 \mu \mathrm{g} / \mathrm{mL})$ was mixed with $625 \mu \mathrm{L}$ of Folin- Ciocalteu reagent $(0.2 \mathrm{~N})$. After $5 \mathrm{~min}, 500 \mu \mathrm{L}$ of aqueous sodium carbonate $\left(\mathrm{Na}_{2} \mathrm{CO}_{3}, 75 \mathrm{~g} / \mathrm{l}\right)$ were added. After $2 \mathrm{~h}$ of incubation in the dark at room temperature, the absorbances were measured at $760 \mathrm{~nm}$ against a blank $(0.5 \mathrm{~mL}$ Folin-Ciocalteu reagent $+1 \mathrm{~mL} \mathrm{Na}_{2} \mathrm{CO}_{3}$ ) by using spectrophotometer. The experiments were carried out in triplicate. A standard calibration curve was plotted using gallic acid $(0-50 \mu \mathrm{g} / \mathrm{mL})(\mathrm{R} 2=0.99)$. The results were expressed as $\mathrm{mg}$ of gallic acid equivalents (GAE)/100 mg of extract.

Total flavonoids - The total flavonoids were estimated according to the Dowd method as adapted by Lamien-Meda et al. (2008). $0.75 \mathrm{~mL}$ of methanolic $\mathrm{AlCl}_{3}(2 \%)$ were mixed with 0.75 $\mathrm{mL}$ of methanolic extract solution $(100 \mu \mathrm{g} / \mathrm{mL})$. After 10 min of incubation, the absorbances were measured at $415 \mathrm{~nm}$ against a blank (mixture of $0.75 \mathrm{~mL}$ methanolic extract solution and 0.75 $\mathrm{mL}$ methanol) by using spectrophotometer and compared to a quercetin $(0-50 \mu \mathrm{g} / \mathrm{mL})$ calibration curve $\left(R^{2}=0.99\right)$. The data obtained were the means of three determinations. The amounts of flavonoids in plant extracts were expressed as $\mathrm{mg}$ of quercetin equivalents $(\mathrm{QE}) / 100 \mathrm{mg}$ of extract.

Infra-red analysis - The dry extract of CA is mixed in anhydrous $\mathrm{KBr}$, the resulting powder is subjected to a high pressure (10000 psi) using a press to obtain a tablet. The IR spectra of the different products are recorded, using $\mathrm{KBr}$ pellets, with a Fourier Transform Apparatus (FTIR) type Perkin Elmer Spectrum Bx (application software: Spectra Manager). We used $2 \%$ of the extracts ( $2 \mathrm{mg}$ of extract and $98 \mathrm{mg}$ of $\mathrm{KBr}$ ) to make the pellets for IR spectrophotometric analysis.

\section{Antioxydante activity in vitro}

FRAP (iron (III) reducing activity) - The FRAP assay was performed according to LamienMeda et al. (2008). A volume of $0.5 \mathrm{~mL}$ of each extract $(1 \mathrm{mg} / \mathrm{mL})$ was mixed with $1.25 \mathrm{~mL}$ of phosphate buffer $(0.2 \mathrm{M}, \mathrm{pH} 6.6)$ and $1.25 \mathrm{~mL}$ of aqueous potassium hexacyanoferrate $\left[\mathrm{K}_{3} \mathrm{Fe}(\mathrm{CN})_{6}\right]$ solution (1\%). After $30 \mathrm{~min}$ of incubation at $50^{\circ} \mathrm{C}$, $1.25 \mathrm{~mL}$ of trichloroacetic acid (10\%) was added and the mixture was centrifuged at $2000 \mathrm{~g}$ during $10 \mathrm{~min}$. Then, the upper layer solution $(0.625$ $\mathrm{mL})$ was mixed with distilled water $(0.625 \mathrm{~mL})$ and a freshly prepared $\mathrm{FeCl}_{3}$ solution $0.125 \mathrm{~mL}$, $0.1 \%$ ). Absorbances were read at $700 \mathrm{~nm}$ on a spectrophotometer and Ascorbic acid was used to produce the calibration curve $(\mathrm{R} 2=0.99)$. The iron (III) reducing activity of the extracts was 
performed in triplicate and expressed in mmol Ascorbic Acid Equivalent per gram (g) of extract.

DPPH (2, 2'-diphenyl-1 picrylhydrazyl)

- Extracts capacity to inhibit 2, 2'-diphenyl-1 picrylhydrazyl (DPPH) radical was evaluated as described by Lamien-Meda et al. (2008). In a 96 micro-well plate, $200 \mathrm{~mL}$ of DPPH (20 $\mathrm{mg} / \mathrm{L}$ ) and $100 \mathrm{~mL}$ of sample were incubated in dark for $10 \mathrm{~min}$, following a reading at $517 \mathrm{~nm}$ (BioTek Instruments, USA). Quercetin was used to generate a standard curve $(\mathrm{y}=-27.94 \mathrm{x}+8.15 ; \mathrm{r}$ $2>0.99$; $\mathrm{P}<0.000$ 1). The data expressed in $\mathrm{mg}$ equivalent of quercetin per gram was the average of 2 independent triplicate tests.

\section{Chemical reagents:}

Folin-Ciocalteu reagent, sodium carbonate $\left(\mathrm{Na}_{2} \mathrm{CO}_{3}\right)$, sodium hydroxide, gallic acid, quercetin, aluminium trichloride $\left(\mathrm{AlCl}_{3}\right)$, were purchased from Sigma Aldrich chemie (Steinheim, Germany); ammonium ferric citrate, anhydrous $\mathrm{KBr}$, potassium persulfate, DPPH (2, 2'-diphenyl-1picrylhydrazyl), trichloroacetic acid were supplied by Fluka chemie (Buchs, Switzerland); acetic anhydride, ferric trichlorure, chloroform, ethanol, methanol and potassium hexacyanoferrate $\left[\mathrm{K}_{3} \mathrm{Fe}(\mathrm{CN})_{6}\right]$ were sourced from Probalo (Paris, France).

Animal care and experimental procedures

Adult female albino Wistar rats, 7 to 8 weeks old, weighing $253.17 \pm 3.28 \mathrm{~g}$ were accommodated into Establishment for Breeding and Use of Laboratory Animals of University of Agricultural Science and Veterinary Medicine (UASVM), ClujNapoca, Romania. Rats were housed in standard polypropylene cages, at optimum density and in standard laboratory conditions (temperature 25 $\pm 1{ }^{\circ} \mathrm{C}$, relative humidity $55 \pm 5 \%$, and $12 \mathrm{~h}$ light/ dark cycle). The rats were allowed free access to water.

Bioethics. All the procedures performed on laboratory animals, comply with the Directive 2010/63/EU, and Romanian national low $43 / 2014$ for protection of animals used for scientific purposes. The project was approved by the Committee for Bioethics and Research Ethics of UASVM (accord no. 69 / 30.05.2017), and the Veterinary Sanitary Direction and Food Safety (project authorization no. 74 / 14.06.207).

Toxicity tests - The extracts wereadministered by gavage (orally) using an esophageal tube. For the acute toxicity evaluation of the extracts, a group of 6 rats received a single dose of $3000 \mathrm{mg}$ / kg b.w. of CA. The extracts were administered to the animals for a volume not exceeding $0.5 \mathrm{ml}$ after the preparation of a concentration of plant extract of $200 \mathrm{mg} / \mathrm{ml}$. After administration of the CA extract, the animals were observed for 2 hours long. After reestablishing a normal diet (water, pellets), the animals were then observed at 24, 48 and 72 hours after which the cumulative number of deaths in each batch was noted.

Anti-obesity activity - The effect of the extracts on food intake and weight was evaluated according to the method described by Van Heerden et al. (2007). The rats were divided into two groups of eight animals each and fed on hyper lipidic diet. The first group received a daily dose of $400 \mathrm{mg} / \mathrm{kg}$ b.w. of CA while the second group or control received only the vehicle (water). All the sixteen rats had free access to hyper lipidic food and water for three weeks long. Anorexigenic potential was determined by daily measurement of food consumption and by measuring their body weight every three days using an electric scale.

\section{Biochemical parameters}

On the $21^{\text {st }}$ day of the experiment, the eight rats in each group were anesthetized after 12 hours of fasting with isofuran solution. The blood was collected with capillary tubes at the orbital retino plexus in dry tubes and centrifuged at $3000 \mathrm{~g}$ for $10 \mathrm{~min}$ to obtain the serum. Serum was immediately removed and frozen at $-20^{\circ} \mathrm{C}$ until use. The liver, kidney, abdominal fat, brain and heart were removed, rinsed with ice-cold $0.9 \%$ $\mathrm{NaCl}$ solution (P/V), and weighed.

The serum was analyzed using a semiautomatic screen-point. STAT-FAX 1904 Plus Global Medical Instrumentation Inc. 6511 Bunker Lake Blvd. Ramsey Minnesota, 55303,

Assay kits are used to determine blood glucose, lipid profile (triglycerides, cholesterol) as well as markers of liver lesions and stress in the serum (creatinine, total protein, albumin, aspartate aminotransferase, alanine amino transferase).

Liver and kidney samples were prepare by homogenisation with a phosphate buffer at pH 7.35 (Gal et al., 2013). The obtained protein extracts were analyzed for total protein content, superoxide dismutase (SOD) activity, glutathione peroxidase (GPx) activity, lipid peroxidation and protein oxidation. 
The protein content of liver and kidney extracts was determined using a Protein Assay Kit Bio-Rad, based on Bradford's method (Bradford, 1976). GPx and SOD activities were achieved using the commercial kits Ransel and Ransod, respectively (Rand ox Laboratories Ltd., Crumlin, UK) according to the manufacturer's instructions. In both cases, a semiautomatic analyzer MasterPlus Screen (Hospitex Diagnostics, Florence, Italy) was used.

Lipid peroxidation level was assessed by measuring the concentration of malonyl dialdehyde (MDA), based on the reaction with thiobarbituric acid (TBA) (Gal et al., 2013).

Proteins oxidation level quantified as the level of carbonylation was carried out by using a method based on the reaction of carbonyl groups with 2.4-dinitrophenylhydrazine (DNPH) (Gal et al., 2013).

\section{Statistical analysis}

All data are reported as the mean \pm SEM. To assume Gaussian distribution normality distribu- tion was checked by D'Agoustino and Pearson omnibus normality test. Data analysis was done by one-way analysis of variance ANOVA, followed by post hoc Tukey's range test and paired t Student test. Statistical significance was at $p<0.05$. Statistical values and figures were obtained using Graph Pad Prism version 5.0 for Windows.

\section{Results and discussions Phytochemical investigation}

The DPPH test is the indirect method for determining the antioxidant activity which is based on the ability of the stable free radical 2,2-diphenyl-1-picrylhydrazyl to react with hydrogen donors including phenols (Roginsky and Lissi, 2005) and The FRAP assay measured the ability of extract to reduce $\mathrm{Fe}^{3+}$ to $\mathrm{Fe}^{2+}$. CA also showed a capacity to neutralize the DPPH radicals and to reduce the ferric ion by the FRAP method (Table 1). The plant has a lower activity than

Table 1: The antioxydant capacity of Caralluma acutangula extract (mean \pm S.E.M.)

\begin{tabular}{|c|c|c|c|c|}
\hline \multirow[t]{2}{*}{ Extract } & \multicolumn{2}{|c|}{ Anti oxydante test } & \multicolumn{2}{|c|}{ Phytochemical analysis } \\
\hline & $\begin{array}{c}\text { DPPH } \\
\text { (mgQE/g) }\end{array}$ & $\begin{array}{c}\text { FRAP } \\
(\mathrm{mmolEAA} / \mathrm{g})\end{array}$ & $\begin{array}{c}\text { TPC } \\
(\mathrm{mgGAE} / 100 \mathrm{mg})\end{array}$ & $\begin{array}{c}\text { TFC } \\
(\mathrm{mgQE} / 100 \mathrm{mg})\end{array}$ \\
\hline Extract of CA $(1 \mathrm{mg} / \mathrm{ml})$ & $10.82 \pm 0.09$ & $0.7 \pm 0.01$ & $36.21 \pm 1.36$ & $4.84 \pm 0.31$ \\
\hline Quercetin (1 mg/ml) & & $1.40 \pm 0.10$ & & \\
\hline
\end{tabular}

S.E.M = Standard Error of the Mean (Triplicate); Mg QE/g: mg quercetin equivalent/gram of extract, mmol EAA/g : millimole Ascorbic Acid Equivalent / gram of extract, TPC: Total phenolic content; TFC: Total flavonoid content, mgGAE/g: mg gallic acid equivalent/gram

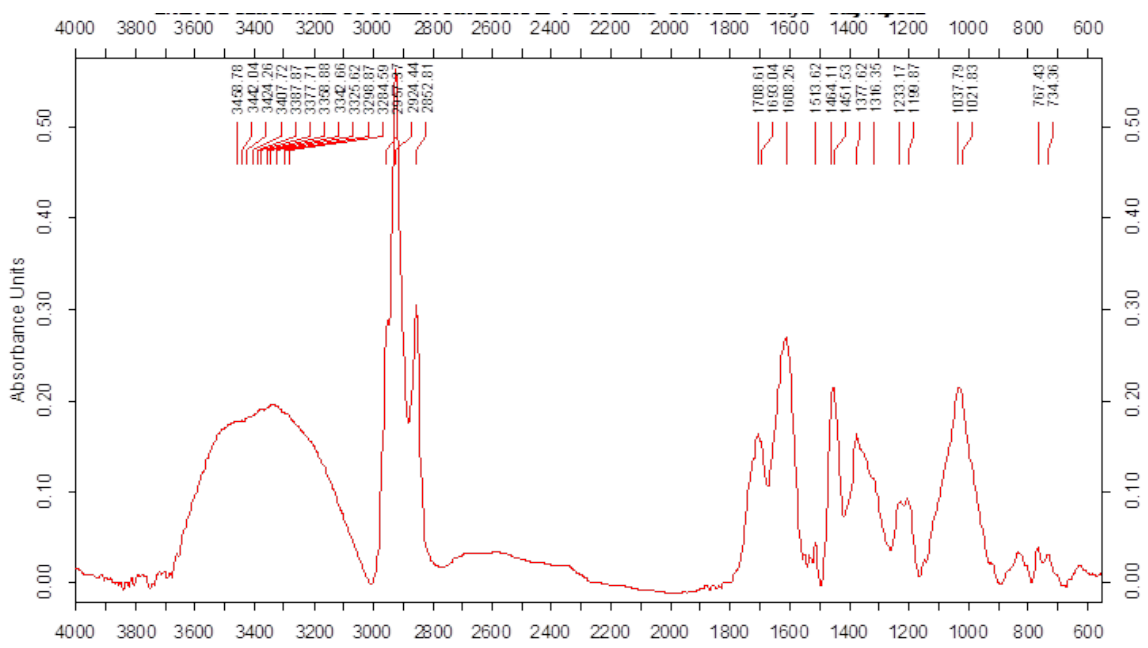

Figure 1. Infra-red spectra of the Caralluma acutangula extract contains significant amounts of phenolic compounds 


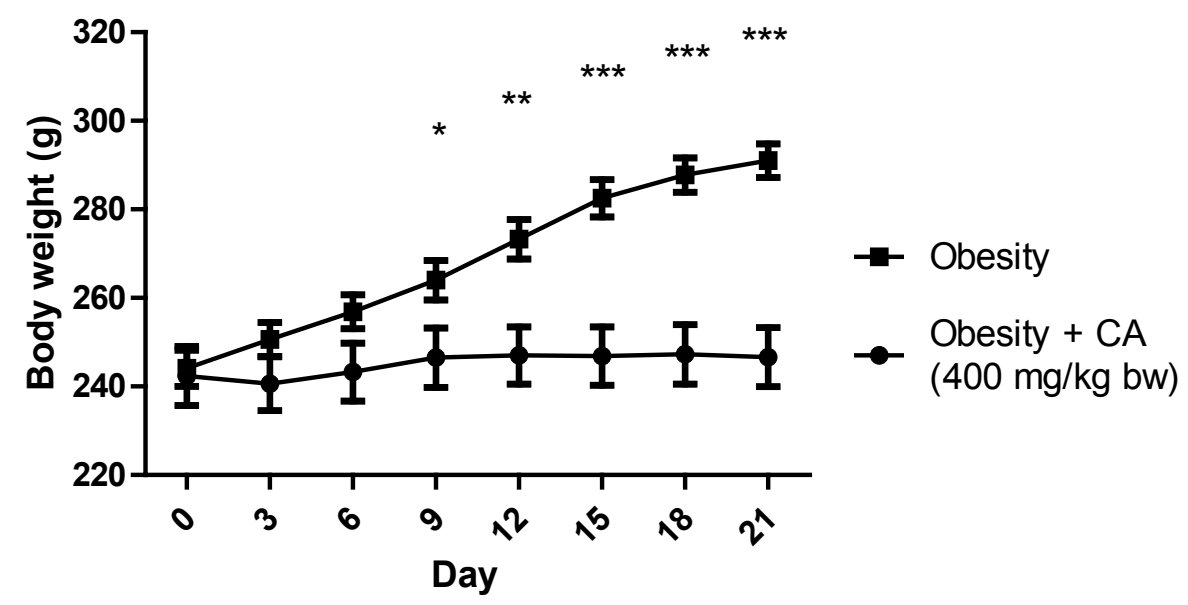

Figure 2. Therapy with Caralluma acutangula extract prevents the body weight gain in rats fed on hypercaloric $\operatorname{diet}\left(* \mathrm{p}<0.05,{ }^{* *} \mathrm{p}<0.01,{ }^{* * *} \mathrm{p}<0.001\right)$,

(Mean \pm SEM, for 8 animal/group., paired t test)
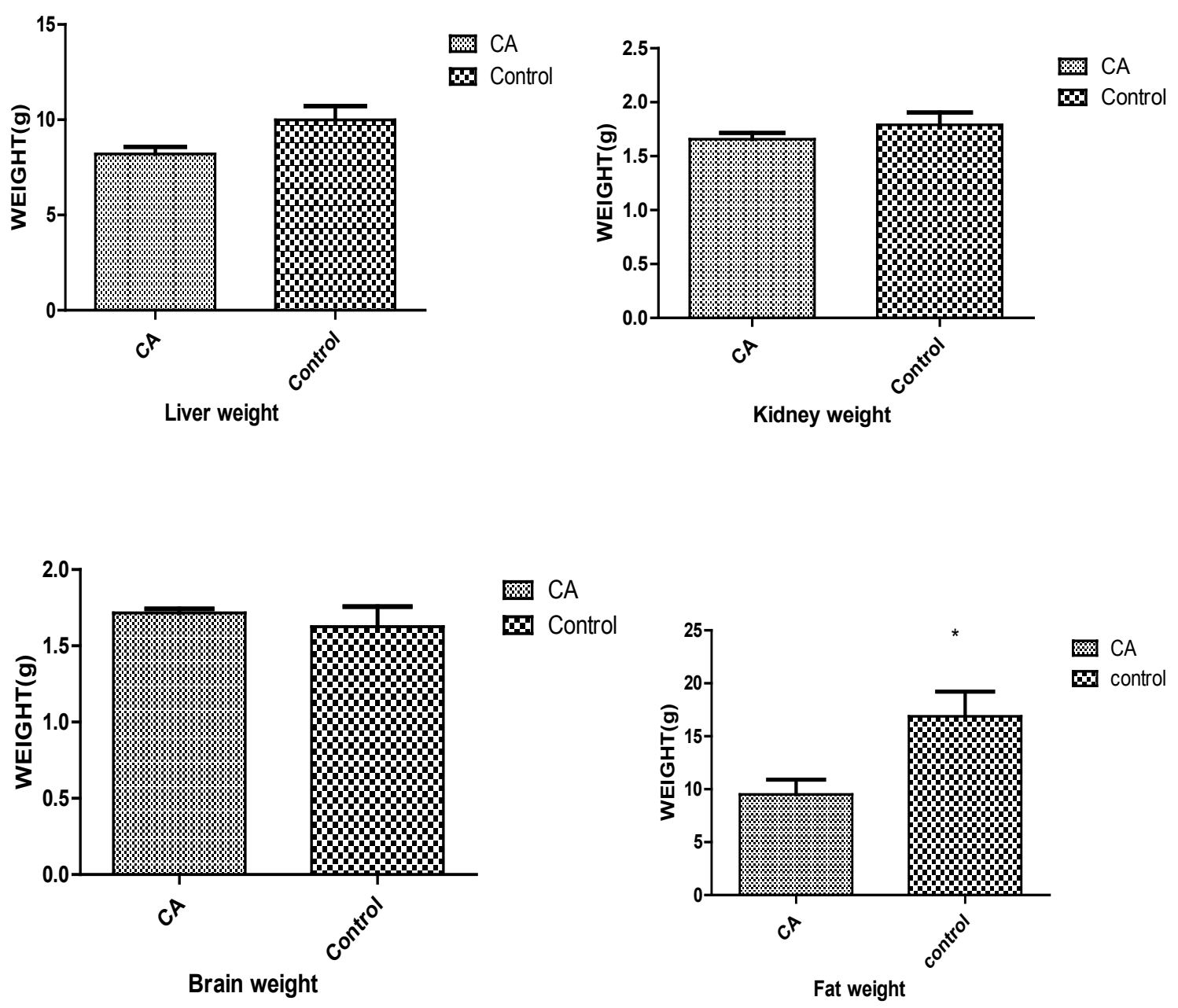

Figure 3: Effects of Caralluma acutangula extract on organs weight. ( $\left.{ }^{*} \mathrm{p}<0.05\right)$, (mean \pm SEM) (8 animals / group) unpaired, two tailed T test 
Table 2: Effect of Caralluma acutangula (CA) on body weight and food intake in in rats fed on hyperlipidic diet (HLD)

\begin{tabular}{cccccc}
\hline Groups & $\begin{array}{c}\text { Initial } \\
\text { weight }(\mathbf{g})\end{array}$ & $\begin{array}{c}\text { Final weight } \\
\text { (g) }\end{array}$ & $\begin{array}{c}\text { Weight gain } \\
\text { (g) }\end{array}$ & $\begin{array}{c}\text { Foods intake } \\
\text { (g) }\end{array}$ & $\begin{array}{c}\text { Percentage of } \\
\text { body weight } \\
\text { gain (\%) }\end{array}$ \\
\hline $\begin{array}{c}\text { Control group } \\
\text { HLD }\end{array}$ & $\begin{array}{c}251.16 \pm \\
14,6\end{array}$ & $290 \pm 38.5^{*}$ & $38.83 \pm 15.35^{*}$ & $67.25 \pm 11.7^{*}$ & $15 \pm 1.44^{*}$ \\
$\begin{array}{c}\text { Group test } \\
\text { HLD+ CA }\end{array}$ & $241.16 \pm 21,6$ & $235.83 \pm 16.1$ & $-5.33 \pm 13.1$ & $53.95 \pm 7.1$ & $-2 \pm 0.39$ \\
\hline
\end{tabular}

(mean \pm SEM) (8 animals / group) (unpaired, two tailed $\mathrm{T}$ test, ${ }^{*} \mathrm{p}<0.05$

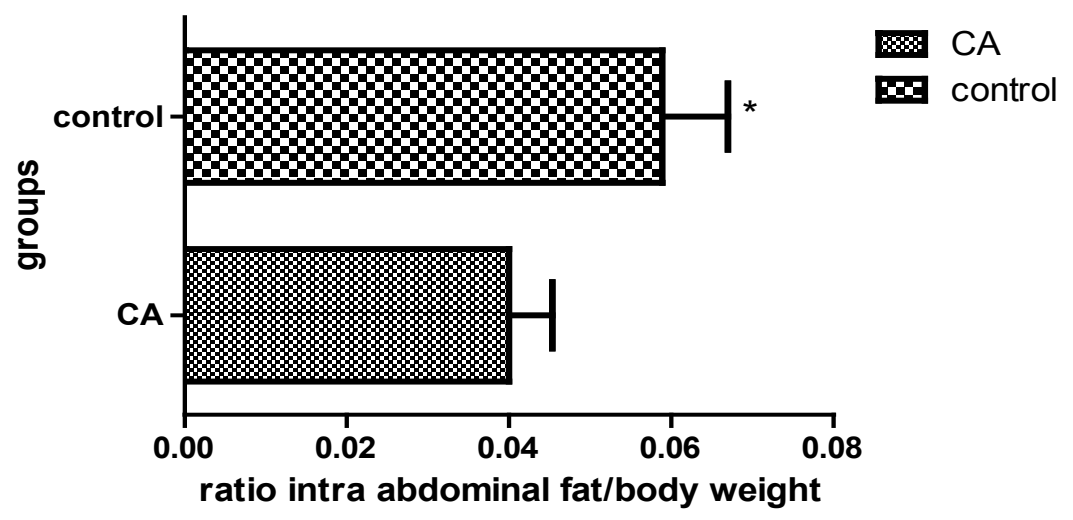

Figure 4: Effects of Caralluma acutangula extract on intra-abdominal fat/body weight ratio.

(* $\mathrm{p}<0.05)$, (mean \pm SEM) (8 animals / group) unpaired, two tailed T test

Quercetin, the reference molecule, but it still has significnat antioxidant capacity.

CA extract was rich in flavonoids $(4.98 \pm$ $0.31 \mathrm{mg} \mathrm{QE} / 100 \mathrm{mg})$ and polyphenol $(36.21 \pm 1.36$ mg GAE/100mg of extract) (Table 1). The analysis of the vibration frequencies of the bonds obtained from the infra-red spectra of the extract showed that the plant extract has a phenolic nucleus (3500-3300 cm -1 and 1300-1000 cm -1), carbonyl functions (1715-1690 cm-1), C-O function of ethers (1150-1020), alcohol functions $(\mathrm{OH})$ and aromatic unsaturations $\mathrm{C}=\mathrm{C}(1500$ $1450 \mathrm{~cm}-1$ ) (Fig. 1). This IR spectrum showed that CA extract contains significant amounts of phenolic compounds that can be quantified by standard methods. Poliphenols are widelly found compounds in various plants with well known antioxidant activity (Lamien-Meda, et al., 2008).

\section{Toxicity tests.}

The results showed that up to $3000 \mathrm{mg} / \mathrm{kg}$ of body weight CA extracts showed no mortality, and no clinical signs of toxicity. The LD50 value is therefore greater than $3000 \mathrm{mg} / \mathrm{kg}$ body weight. Considering the toxicity scale of Hodge and Sterner (1943), we can consider that the macerate of the CA is not toxic orally on Wistar rats.

\section{Anti-obesity activity}

After 21 days of experimentation the animals fed with only on HD without treatment showed a body weight gain of approx. $15 \%$, while CA-HD treated group had a body weight loss of $2 \%$. The difference was visible starting to the $9^{\text {th }}$ day, and it increased significantly up to the end of the study (Fig. 2) (Table 2). The weight of the internal organs (liver, kidney, brain) had no changes between the experimental groups (Fig 3). The In HD animals the body weight gain relayed on accumulation 
of the abdominal body fat, while the CA therapy prevented the abdominal obesity (Fig. 3, 4).

CA extract showed also a reduction in food intake (Table 2), which could justify the weight reduction. Indeed, some medicinal plants as Hoodia gordonii (Van Heerden, 2008, Wennert, 2012) and Caralluma fimbriata (Kuriyan et al., 2007) are able to reduce the weight due to their anorectic potential.

Obesity is considered a chronic inflammatory state, adipocytes and preadipocytes are sources of production of proinflammatory cytokines, including TNF-a, IL-1 and IL-6; these molecules are responsible for the enhancement of oxidative stress markers as malondialdehyde (MDA) (Alba et al., 2011). Oxidative stress, consequently, enhances the response of the body's antioxidant system, including various endogenous substances (glutathione, uric acid, bilirubin, melanin, melatonin, lipoic acid, etc.) and antioxidant enzymes such as superoxide dismutase (SOD), catalase (CAT), glutathione peroxidase (GPX), etc. In three weeks of treatment, CA extracts provided a protective effect on liver manifested by regulating the level of antioxidant enzymes (Fig. 5); the activity of antioxidant enzymes such as SOD and GPX is enhanced by the interleukins. The lipid accumulation seemed to have no consequences on hepatocytes integrity and function, as long as the plasma proteins and transaminases (ASAT, ALAT) remained practically unchanged. One the other
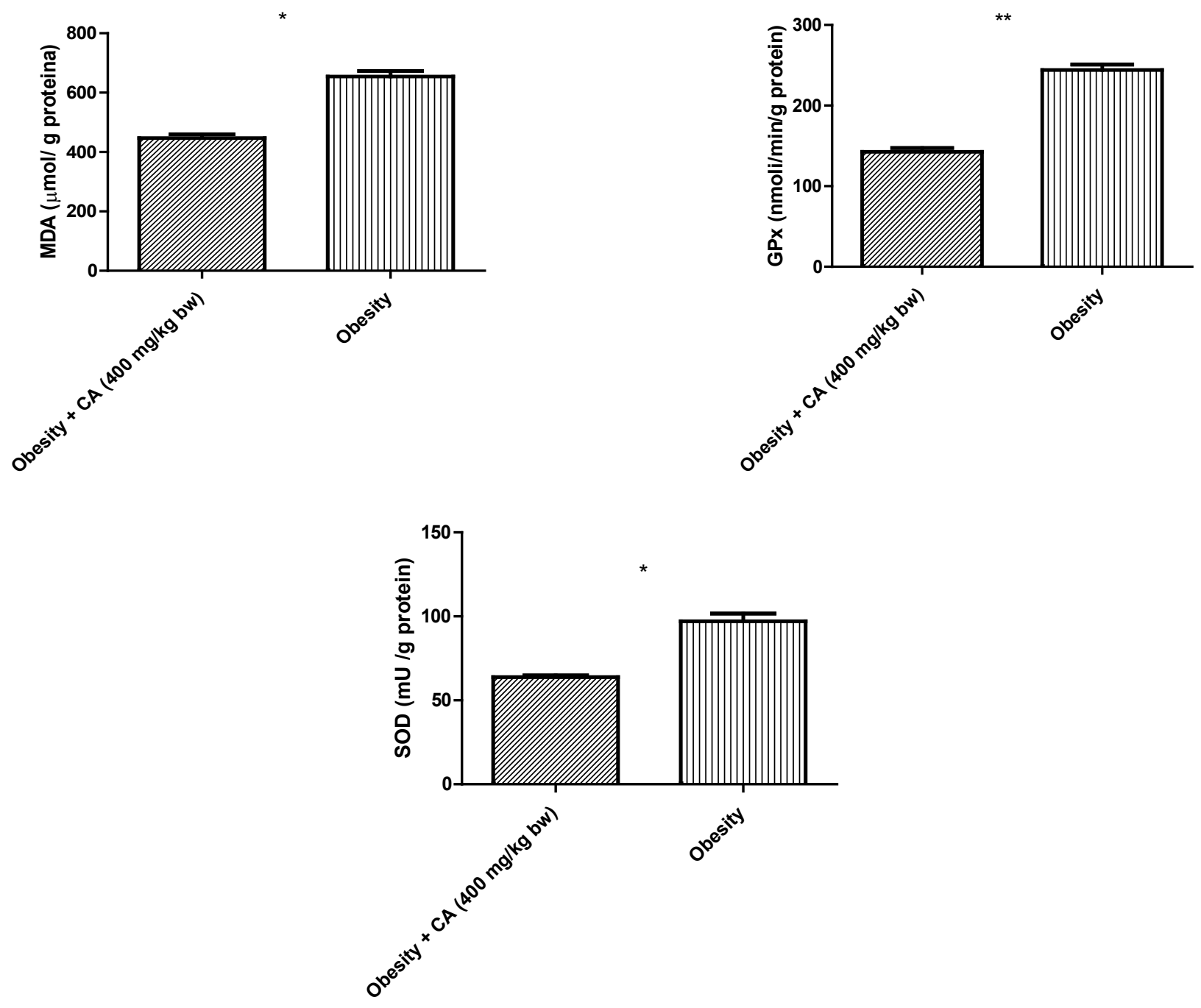

Figure 5: Effects of Caralluma acutangula extract on liver oxidative stress parameters MDA, GPx and SOD. (* $\mathrm{p}<0.05, * * \mathrm{p}<0.01)$, (mean $\pm \mathrm{SEM})(8$ animals / group) unpaired, two tailed T test 
hand the extract had no effect on anti-oxidant enzyme in kidney (Fig. 6).

Obesity is often reflected in plasma biochemistry by elevation in serum triglycerides and hyperglycemia. The CA extract showed a reduction in triglyceride levels $(136.57 \pm 13.82$ $\mathrm{mg} / \mathrm{dL}$ ) compared to the control group (206.02 $\pm 23.82 \mathrm{mg} / \mathrm{dL}$ ) (Table 3), $(\mathrm{p}<0.05)$; as well as a reduction in blood glucose in the CA-HD rats $(187.74 \pm 31.16)$ compared to the HD $(230.96 \pm$ 79.07).

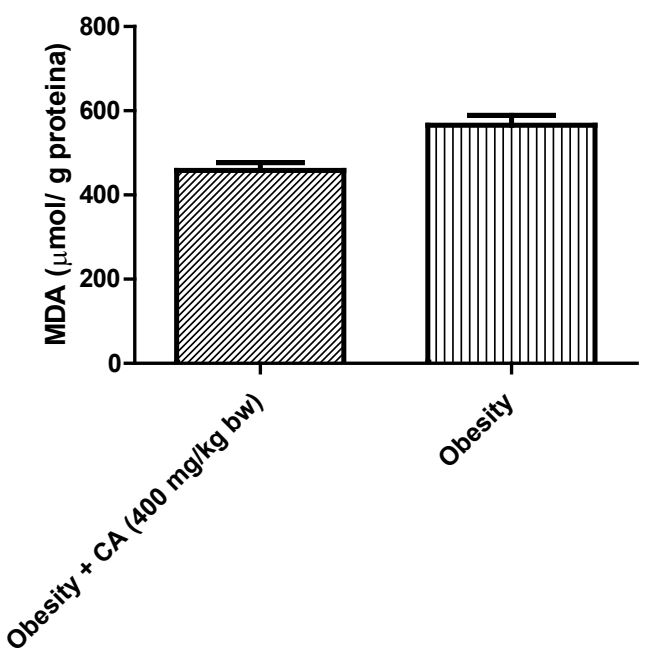

The mechanisms responsible for CA activity is still a controversy. CA could act by inhibiting digestive enzymes such as lipase, an enzyme involved in lipid dygestion (Yun et al., 2012), which results in a decrease abdominal fat mass (Fig. 4), but it has no effect on the weight of the liver, kidney, or brain. Other possible mechanisms might be provided by certain flavonoids and polyphenols; they prevent the obesity by acting as anorectic agents, lipase inhibitor, or stimulator of thermogenesis (Mahnaz et al., 2012). Various dietary bioactive compounds like genistein,
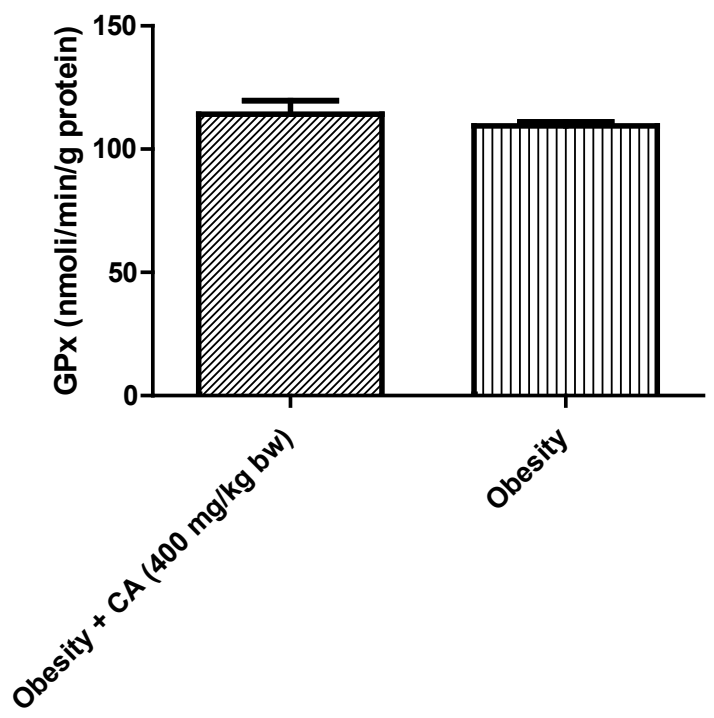

Figure 6.: Effects of Caralluma acutangula extract on kidney oxidative stress parameters MDA, GPx and SOD. (mean \pm SEM) (8 animals / group) unpaired, two tailed T test 
2. Bradford MM (1976): A rapid and sensitive method for the
Table 3: Effects of Caralluma acutangula extract on plasma biochemistry in rats fed on hyperlipidic diet (HD) (mean \pm S.E.M.)

\begin{tabular}{ccccccccc}
\hline & $\begin{array}{c}\text { Triglyceride } \\
(\mathbf{m g} / \mathbf{d L})\end{array}$ & $\begin{array}{c}\text { Cholesterol } \\
(\mathbf{m g} / \mathbf{d L})\end{array}$ & $\begin{array}{c}\text { ASAT } \\
(\mathbf{U} / \mathbf{L})\end{array}$ & $\begin{array}{c}\text { ALAT } \\
(\mathbf{U} / \mathbf{L})\end{array}$ & $\begin{array}{c}\text { Glucose } \\
(\mathbf{m g} / \mathbf{d L})\end{array}$ & $\begin{array}{c}\text { Total } \\
\text { protein } \\
(\mathbf{g} / \mathbf{d L})\end{array}$ & $\begin{array}{c}\text { Albumin } \\
(\mathrm{g} / \mathbf{d L})\end{array}$ & $\begin{array}{c}\text { Creatinin } \\
(\mathbf{m g} / \mathbf{d L})\end{array}$ \\
\hline $\begin{array}{c}\text { Group } \\
\text { test }\end{array}$ & $\mathbf{1 3 6 . 5 7 \pm 1 3 . 8 2 *}$ & $78.25 \pm 5.79$ & $77.86 \pm 8.30$ & $41.04 \pm 8.43$ & $\mathbf{1 8 7 . 7 4 \pm 3 1 . 1 6 *}$ & $13.30 \pm 3.16$ & $4.28 \pm 0.29$ & $0.58 \pm 0.1$ \\
$\begin{array}{c}\text { HD+ CA } \\
\begin{array}{c}\text { Control } \\
\text { group } \\
\text { HD }\end{array}\end{array}$ & $\mathbf{2 0 6 . 0 2 \pm 2 3 . 8 2}$ & $92.06 \pm 8.59$ & $88.72 \pm 9.95$ & $39.17 \pm 6.77$ & $\mathbf{2 3 0 . 9 6 \pm 7 9 . 0 7}$ & $12.42 \pm 1.61$ & $4.74 \pm 0.45$ & $0.53 \pm 0.04$ \\
\hline
\end{tabular}

$\left({ }^{*} \mathrm{p}<0.05,{ }^{* *} \mathrm{p}<0.01\right),($ mean $\pm \mathrm{SEM})(8$ animals $/$ group $)$ unpaired, two tailed $\mathrm{T}$ test; ASAT $=$ Aspartate aminotransferase, ALAT $=$ ALanine Amino Transferase

epigallocatechin gallate, quercetin, resveratrol affect the adipocytes during specific stages of development (Srujana, et al., 2008); while the o-coumaric acid and rutin downregulates the Glycerol-3-Phosphate Dehydrogenase activity (Chin-Lin et al., 2007).

\section{Conclusion}

In conclusion, on hyperlipidic diet obesity model, CA effectively prevented the body weight gain, reduced the food intake and oxidative stress. Notably, no adverse effects were notice on both acute and chronic administration. Despite the fact that this plant is used traditionally in Burkina Faso to manage the body weight, this study represented the first evidence that the extracts of CA possess effective anti-obesity and antioxidant activities. Future investigations are needed, including more detailed phytochemical studies to identify the bioactive compound responsible of weight reduction, and to elucidate its cellular and molecular mechanism.

Acknowledgments: This research project was supported by Francophone University Association (AUF) throughout Doctoral Scholarships Programme "Eugen Ionescu" 2016-2017.

Declaration of interests - The authors report no conflict of interest.

\section{References}

1. Alba F, Eduardo M, Mirandeli B, Jaime E, Ángel M, Cesar E, Durante M, Graciela S, Carmen V and José AM (2011). Inflammation, oxidative stress, and obesity. Int. J. Mol. Sci., 12, 3117-3132. quantitation of microgram quantities of protein utilizing the principle of protein-dye binding. Anal Biochem, 72: 248-254.

3. Chin-Lin H and Gow-Chin Y (2007). Effects of flavonoids and phenolic acids on the inhibition of adipogenesis in 3T3-L1 adipocytes. J. Agric. Food Chem., 55 (21),8P.

4. Gal AF, Andrei S, Cernea C, Taulescu M, Catoi C (2013). Effects of astaxanthin supplementation on chemically induced tumorigenesis in Wistar rats. Acta Veterinaria Scandinavica, 54:50

5. Halaweish F, Huntimer E, Khalil A (2004). Polyoxy pregnane glycosides from Caralluma retrospiciens. Phytochem Anal., 15:189-194.

6. Harish CD, Surjeet S, Bharathi A, Ikhlas AK and Yashbir SB (2012). PharmacologicalReview of Caralluma R.Br. with Special Reference to Appetite Suppression and AntiObesity. Journal of Medicinal Food. 15(2), 108-119.

7. Hodge HC, Sterner JH (1943). Determination of substances acute toxicity by DL50. American Industriel Hygien Association, 10, 93.

8. Kuriyan R, Raj T, Srinivas SK, Rajendran M-VR and Kurpad AV (2007). Effect of Caralluma fimbriata extract on appetite, food intake and anthropometry in adult indian men and women, Appetite, 48, 338-344.

9. Lamien-Meda A, Lamien CE, Compaoré MMY, Meda RNT, Kiendrebeogo M, Zeba B, Millogo JF and Nacoulma OG (2008). Polyphenol content and antioxidant activity of fourteen wild edible fruits from Burkina Faso. Molecule, 13(3): 581-594.

10. Mahnaz K, Che Wan JWMR, Geoffrey AC, Iman Y (2012). Potential of traditional medicinal plants for treating obesity: a review, International Conference on Nutrition and Food Sciences; 39, 6P.

11. Mohammed A, Essam A and Eric T (2000). Pregnane Glycosides from Caralluma russeliana, J. Nat. Prod., 63:1451-1453.

12. Roginsky V, Lissi EA (2005). Review of methods to determine chain-breaking antioxidant activity in food. Food Chem., 92:235-254. 
13. Schmelzer GH, Gurib-Fakim A (2013). "Medicinal plants 2" PROTA

14. Seidell JC, Flegal KM (1997). Assessing obesity: classification and epidemiology. British Medical Bulletin, 53:238-252.

15. Singleton LV, Orthofer $R$ and Lamuela-Raventos RR (1999). Analysis of total phenol and other oxydation substractes and antioxidants by mean of Folin- Ciocalteu reagent. Methode in Enzymology, 299:152-178.

16. Srujana R, Mary AD and Clifton AB (2008). Phytochemicals and regulation of the adipocyte life cycle. Journal of Nutritional Biochemistry, 19:717-726.

17. Van Heerden FR (2008). Hoodia gordonii: A natural appetite suppressant. Journal of Ethnopharmacology, $119 ; 434-437$.
18. Wennert AL (2012). Hoodia gordonii (Masson) Sweet ex Decne: une plante d'Afrique du Sud, de son utilisation traditionnelle vers un éventuel avenir thérapeutique. Mémoire de thèse, Université de Lorraine, p.197.

19. Wilson K, Bernard W, Hillary R and Gabriel K (2014). A study of the medicinal plants used by the Marakwet Community in Kenya. Journal of Ethnobiology and Ethnomedicine, 10:24, https://doi.org/10.1186/17464269-10-24.

20. Woods SC, Seeley RJ, Porte Jr D, Schwarts MW (1998). Signals that regulate food intake and energy homeostasis. Science, 280:1378-1383.

21. Yun ML, Young SK, Youngseop L, Junghyun K, Hang S, Joo HK and Jin SK, (2012). Inhibitory activities of pancreatic lipase and phosphodiesterase from korean medicinal plant extracts. Phytotherapy Research, 26:778-782. 